\title{
Estimation of Probabilistic Seismic Hazard for Marine Structures: A Case Study for Haydarpaşa Port
}

\author{
(1) Aydın Mert \\ Boğaziçi University, Kandilli Observatory and Earthquake Research Institute, Department of Earthquake Engineering, \\ İstanbul, Turkey
}

\begin{abstract}
The size and importance of maritime transportation in world trade are well known. The number of ports, which is one of the most important elements of maritime transportation, is increasing day by day not only in our country but also throughout the world. Many active fault systems in our country are located at sea. In the Marmara Region in particular, most active branches of the North Anatolian Fault system pass through the Sea of Marmara. When offshore structures such as ports are constructed in high-seismicity zones such as the Sea of Marmara, conducting site-specific seismic hazard studies is necessary to reduce the seismic risk of offshore structures. In 2007, the first Turkish Seismic Design Code for Port Structures was published, which introduced new design concepts in the seismic design of offshore structures. According to this code, the design can be finalized in three basic steps: assessment of regional seismicity, estimation of geotechnical hazards, and soil-structure interaction analysis of offshore structures. Nowadays, the first Turkish Seismic Design Code for Port Structures is on the verge of a major update, which was published as a draft report in May 2019. In this manuscript, site-specific probabilistic seismic hazard analysis is needed to determine the seismic hazard associated with typical port sites. Considering this new draft code as a guideline document, we developed consistent seismic hazard studies for offshore structures within the Haydarpaşa Port sites. Unlike the old one, this new document identifies four different levels of ground motion: minimum damage level earthquake $\left(T_{R}=72\right)$, limited damage level earthquake $\left(T_{R}=144\right)$, controlling damage level earthquake $\left(T_{R}=475\right)$, and maximum considered earthquake $\left(\mathrm{T}_{\mathrm{R}}=2.475\right)$.
\end{abstract}

\section{Keywords}

Probabilistic seismic hazard assessment, Marine structures, Uniform hazard spectra

\section{Introduction}

Most developed countries depend on the smooth functioning of their maritime ports. These ports are essential elements of the complete delivery system, and billions of tons of cargo are handled by ports, thus reflecting that international trade moves by water. Ports also play an important role in providing social, health, safety, and environmental benefits. Any serious or major deterioration or disintegration of these services because of a disaster such as an earthquake or earthquake-induced tsunami or landslides can be the cause of extreme losses across a wide range of socially valued activities and may considerably affect the economic conditions, security, and overall welfare of society.
An earthquake epicenter located close to marine structures or seaports is a direct threat. These marine structures are then exposed to the destructive influence of different levels of earthquakes, which can have disastrous or even catastrophic consequences. Such a natural event can also cause any level of indirect damage to marine structures. Stability and/or integrity problems can become an important risk factor for the marine structures because of strong ground motion or liquefaction. Many catastrophic earthquakes have occurred in recent history; thus, these risks are a reality not only in our country but also in many developed countries with high seismic zones (e.g., HokkaidoNansei-Oki, Japan, 1993; Hyogoken-Nanbu, Japan, 1995;

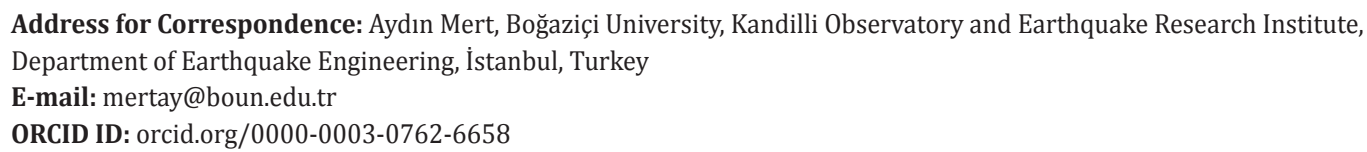

To cite this article: A. Mert, "Estimation of Probabilistic Seismic Hazard for Marine Structures: A Case Study for Haydarpaşa Port." Journal of ETA Maritime Science, vol. 9(2), pp. 74-84, 2021.

${ }^{\circ}$ Copyright 2021 by the Journal of ETA Maritime Science published by UCTEA Chamber of Marine Engineers 
Izmit, Turkey, 1999; Duzce, Turkey, 1999). During these earthquakes, many different marine structures suffer severe damage due to strong shaking of the ground or liquefaction.

The 1993 Hokkaido-Nansei-Oki earthquake caused an estimated economic loss of 13 billion yen in port structures [1]. A handbook was published [2] to describe the proposed methods for evaluating potential liquefaction and the possible preventive methods. The HyogokenNanbu (Kobe) earthquake resulted in an estimated loss of 590 billion yen because of port damage [1]. Thus, a performance-based seismic design concept is introduced as a procedure in which two levels of earthquake motions were specified for design purposes.

After two devastating earthquakes in 1999-the Izmit earthquake on August $17\left(\mathrm{M}_{\mathrm{w}}=7.4\right)$ and the Düzce earthquake on November $12 \quad\left(\mathrm{M}_{\mathrm{w}}=7.2\right)$-many articles and technical documents related to marine structure damages were written. Boulanger et al. [3] classified the structural damages in offshore structures and investigated the real performance of marine ports in a special volume of the journal Earthquake Spectra, which focused on the performance of all structures during these two earthquakes. Gunbak et al. [4] studied a relatively comprehensive list of damage to more than 20 marine structures. Yüksel et al. [5] studied in detail the extent of the damage to marine structures caused by the Kocaeli earthquake. Sumer et al. [6] provided an inventory of damages to marine structures as a result of soil liquefaction. After these catastrophic earthquakes, the General Directorate for Construction of Railways, Harbors, and Airports (RHA) of the Ministry of Transportation of the Turkish Republic organized a commission to prepare a seismic design code in 2005. This commission completed the first seismic design code, which is introduced the performance-based design concept for transportation structures, in the 2007 RHA seismic code [7].

Although the structural distance to fault rupture is at least $20 \mathrm{~km}$, soil liquefaction and the generated extensive soil deformations caused serious damage to marine structures during January 12, 2010, earthquake in Port-au-Prince, Haiti. Similarly, during the M 8.8 Maule earthquake (February 27, 2010) in Chile, liquefaction induced ground failures and warped waterfront structures. The M 7.8 Kaikoura earthquake in New Zealand (2016) excited extensive soil liquefaction and large failure surfaces in the ground at Centre Port, Wellington, eventually causing widespread damage not only to wharves but also to seaport facilities [8].

One of the main purposes of this article is to draw attention to seismic risks in Turkish ports and the size of the losses they may cause. Seismic hazard refers to the level of ground shaking that can cause damage or any other secondary effects such as soil liquefaction and landslides at the Earth's surface due to earthquake activity at a given site in a given period. The relationship between ground motion values and their annual probabilities of exceedance is presented as an output of a seismic hazard assessment.

Evidently, any marine structure located in an active earthquake region should deal with seismic risk management studies. By definition, seismic risk can be interpreted as the anticipated losses as a result of earthquake-induced phenomenon. With the aim of developing proper studies in the field of seismic risk management and to contribute to decision-making processes, this work primarily focuses on site-specific probabilistic seismic hazard analysis of the Haydarpaşa Port site based on the New Turkish Seismic Design Code for Port Structures (NTSDCforPS) (Final report base draft report, interim report-3) [9].

RHA has a seismic code that was prepared in 2007. The code introduced performance-based design objectives for the first time for offshore structures in Turkey. In 2012, the Ministry of Transportation updated the RHA seismic code and organized a group of experts; NTSDCforPS is a product of this decision $[7,9]$. In this manuscript, all evaluations were made considering the final report basis draft report, interim report-3 (May 2019), which is used as a guide for the Turkish Seismic Code for the Constructions of Harbor and Coastal Structures.

\section{Study Area}

A probabilistic earthquake assessment study to obtain the uniform hazard curve for four different levels of ground motion is conducted by concentrating on Haydarpaşa Port in İstanbul. İstanbul is heavily populated, with more than 15.5 million people [10]. It is located in the Marmara Region in the northwestern part of Turkey and produces more than $31 \%$ of the country's grand national product [10]. Consistent with the economic importance of İstanbul, the city has several commercial ports. Haydarpaşa Port is the largest and oldest container port not only in İstanbul but also in the Marmara Region and is the third largest port in the nation.

The port consists of containers for handling and storing general cargo and ro-ro handlings. The short- and longdistance passenger transfers and urban transportation (maritime, railway, and highway) are other main components of the port [13]. The location and general layout of the port are demonstrated in Figure 1, which shows that the Haydarpaşa Port is located close (less than $20 \mathrm{~km}$ ) to the northern branch of the North Anatolian Fault (NAF) system, which crosses the Sea of Marmara. 
Another important issue is related to the study area, especially after the two catastrophic earthquakes in 1999. The entire Sea of Marmara has been identified as a seismic gap in most scientific papers [14]. This scientific reality is one of the reasons we select the Haydarpaşa Port as a study area.

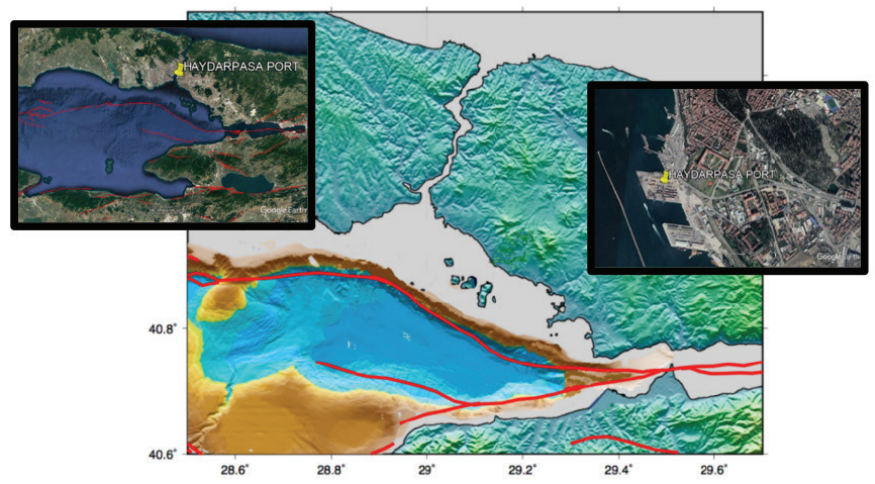

Figure 1. Fault map and bathymetry of Marmara Sea together with the location of the Haydarpașa Port (Bathymetric data based on Kandilli Observatory and Earthquake Research Institute (KOERI) [11] database, Numeric fault model based on Armijo et al. [12]).

\section{Methodology}

One important difference between the RHA seismic code and the NTSDCforPS is that the latter requires design supervision and control services in some specific fields $[7,9]$. In the evaluation and design processes during the implementation of this regulation, design supervision and control services that require the special expertise of civil engineers are compulsory. These engineers must have theoretical and professional knowledge and experience in the relevant field to work in all relevant design stages from the beginning to the end of the project. According to NTSDCforPS [9], site-specific earthquake hazard calculations and earthquake ground motion in time domain fields are subject to design supervision and control services.

Coastal structures are divided into three main classes in terms of use, performance and severity levels expected during and after an earthquake. These classes are presented below.

\section{Important Structures}

- Have strategic importance in terms of security/defense

- Ensures rapid response and evacuation actions

- For toxic, flammable, or explosive materials

- Difficult, expensive, and indispensable after an earthquake

\section{Normal Structures}

- Structures that are not classified as important and simple structures

\section{Simple Structures}

- Structures that can be easily rebuilt after the earthquake - Structures that can be considered to be extensively damaged after severe earthquakes

\section{- Coastal fortifications}

On the basis of this document, the design of new marine structures or evaluating existing marine structures under the effects of an earthquake is explained in chapter 2. RHA seismic code defines three different levels of earthquakes, whereas NTSDCforPS requires four different levels of earthquake ground motions $[7,9]$.

\section{(E-1) Earthquake Level}

Very rare earthquake ground motions, with a $2 \%$ probability of exceedance (PofE) in 50 years, which probabilistically corresponds to a return period $\left(T_{R}\right)$ of 2,475 years.

\section{(E-2) Earthquake Level}

Rare earthquake ground motions, with a $10 \%$ PofE in 50 years, $T_{R}=475$ years.

\section{(E-2-A) Earthquake Level}

Relatively frequent earthquake ground motions, with a $50 \%$ PofE in 30 years, $T_{R}=144$ years.

\section{(E-3) Earthquake Level}

Frequent earthquake ground motions, with a 50\% PofE in 50 years, $\mathrm{T}_{\mathrm{R}}=72$ years.

To identify the classification of the calculation and evaluation methods to be applied, earthquake design classes (EDC) need to be determined, which is based on the coefficient of design spectral acceleration (SA) of the short period defined for DD-2 earthquake ground motion level.

$\mathrm{EDC}=4 \quad \mathrm{~S}_{\mathrm{DS}}<0.33$

$\mathrm{EDC}=3 \quad 0.33 \leq \mathrm{S}_{\mathrm{DS}}<0.50$

$\mathrm{EDC}=2 \quad 0.50 \leq \mathrm{S}_{\mathrm{DS}}<0.75$

$\mathrm{EDC}=1 \quad \mathrm{~S}_{\mathrm{DS}} \leq 0.75$

The seismic performance of port structures is based on the expected earthquake damage. These performance levels (PL) have four categories.

- Minimum damage (MD) PL

- Limited damage (LD) PL

- Controlled damage (CD) PL

- Collapse prevention (CP) PL

\subsection{Probabilistic Seismic Hazard Assessment}

The probabilistic seismic hazard assessment (PSHA) procedure depends on identifying the occurrence of an earthquake as a homogeneous Poisson's distribution and the evaluation of ground motion parameters such as peak ground acceleration (PGA) in a predetermined site from 
ground motion prediction equations. PSHA was introduced by Cornell [15] and further developed by contributions from McGuire [16].

The fundamental contents of the basic seismic hazard assessment procedure can be explained as follows:

Seismic source modeling: This comprises identification of possible seismic sources considering the geological and tectonic systems of the region and the properties of the geometric definition of the seismic source zones (such as area and line sources).

Frequency-magnitude relationship: The seismicity rate for all of the identified seismic sources is characterized by means of recurrence relationships. The magnitude distribution relationship developed by Gutenberg and Richter [17] is used in most studies.

Ground motion prediction equation: The ground motion prediction equation is generally used to predict the decrease in ground motion, which depends on the earthquake magnitude and source-to-site distance considering site geological conditions.

Computations of the seismic hazard can be identified by the following equation, which is an application of the total probability theorem (formula 1 is below):

$$
H(a)=\sum_{i} V_{i} \iint P[A>a \mid m, r] f_{M_{J}}(m) f_{R \mid M_{J}}(r, m) d r d m
$$

In this equation, the hazard $\mathrm{H}$ (a) represents the annual frequency of the earthquakes that produce a ground motion of amplitude A with a value higher than a. The amplitude A may represent PGA, velocity, or displacement, or it may represent the spectral pseudo-acceleration for a given frequency.

The summation in Equation 1 includes all sources; ni represents the annual rate of earthquakes (of a magnitude higher than some threshold values $M o i$ ) in a source $I$. $f M i$ $(m)$ and $f R i \mid M i(r ; m)$ represent the probability density functions based on the magnitude and distance between different locations within the source $i$ and the site in question, respectively. $P(A>a \mid m, r)$ is the possibility that an earthquake with a magnitude $m$ at a distance $r$ can yield a ground motion with amplitude $\mathrm{A}$ at the specific site that is higher than a.

Seismic sources may be either faults or area sources. The source geometries and the calculation of $f R i \mid M i$ are specified differently for these two types of sources.

For fault sources, the common form for calculating P $(A>a \mid m$, $r$ ) is as follows:

$$
\ln A=C_{1}+C_{2} M+C_{3} \ln R+C_{4} R+\varepsilon ; \quad \varepsilon \approx N\left(0, \sigma_{\varepsilon}^{2}\right)
$$

where $\mathrm{R}$ is some measure of distance to the earthquake rupture. For area sources, the general form for calculating $\mathrm{P}(\mathrm{A}>\mathrm{a} \mid \mathrm{m}, \mathrm{r})$ is

$$
\ln A=C_{1}+C_{2} M+C_{3} \ln (R+R Z E R O A)+C_{4} R+\varepsilon ; \quad \varepsilon \approx N\left(0, \sigma_{\varepsilon}^{2}\right)
$$

where $\mathrm{R}$ is the focal distance (assuming a point source), which is computed from the horizontal distance and the source depth $\mathrm{h}$. In the above two equations, $C 1, C 2, C 3, C 4$, and RZEROA are constants, independent of $M$ and $R$.

Either of the above two equations can be transformed into

$$
\sum_{i} P[A>a / m, r]=\phi^{*}\left(\frac{\ln a-\ln A(m, r)}{\sigma_{\zeta}}\right)
$$

in which $\phi$ is the normal complementary cumulative distribution function and $\ln A(m, r)$ is the value of $\ln A$ obtained from Equation 2 or 3 by setting $\varepsilon=0$.

The distribution of magnitude is generally assumed to be doubly truncated exponential, i.e.,

$$
f_{M j}(m)=k_{i} \beta_{i} \exp \left[\beta_{i}\left(m=M_{0 i}\right)\right], \quad M_{0 i} \leq m \leq M_{\text {maxi }}
$$

in which $k_{i}=\left(1-\exp \left[\beta_{i}\left(m=M_{\mathrm{O} i}\right)\right]-1\right.$ is a normalizing constant, $M_{\mathrm{O} i}$ is the threshold magnitude defined earlier, and $M_{\text {maxi }}$ is the largest magnitude that may occur in the source.

\subsection{Seismotectonic System and Seismicity of the Region}

The Marmara Region is situated in a transition zone between the right-lateral strike-slip character of NAF and $\mathrm{N}-\mathrm{S}$ extensional regime of the Aegean Region, which is why it has a complex and heterogeneous fault system together with high seismic activity (Barka and Kandinsky-Cade [18]; Dewey and Şengör [19]; Şengör et al. [20]; Orgulu [21]). The Sea of Marmara is known as a seismic gap along the NAF (Pınar [22]; Toksöz et al. [23]; Pondard et al. [24]; Şengör et al. [25]).

Historical records over more than 2,000 years in the Marmara Region show that the region is frequently exposed to strong shaking, experiencing many different catastrophic earthquakes or earthquake-induced landslides and tsunamis; these disasters may continue to occur in the future [26-28]. During the historical period (from 0 to 1900), about 600 earthquakes were identified in this region, with at least 38 of them being comparatively large shocks with a magnitude $\mathrm{M}_{\mathrm{s}} \geq 6.8$ [29] (Figure 2). 


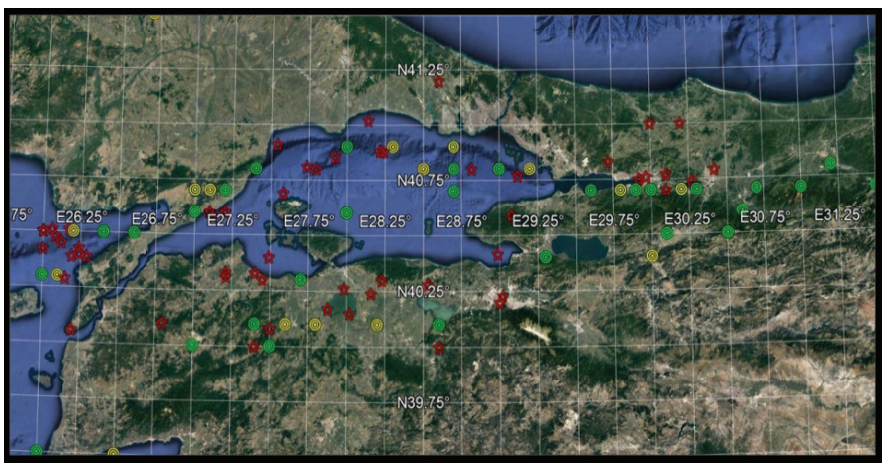

Figure 2. Marmara Region earthquakes during 32 AD-2002 according to Ambraseys, 2002. Yellow and green circles demonstrate $M \geq 6$ and $M \geq 7$ earthquakes respectively during $32 \quad A D-1900$ (Ambraseys [26]). The red stars represent $5 \leq M \leq 7.6$ earthquakes during 1900-2020

Seismicity during the instrumental period (after 1900) and recent detailed micro-earthquake studies verify the same fact. During the instrumental period, earthquake activity within the region of the Sea of Marmara can be determined as a swarm-type activity (Figure 3). Using earthquake catalogs that contain earthquake records from historical and instrumental periods, Kalkan et al. [30] demonstrated the distribution of all evident events that are equal to or higher than magnitude 6 after the year 1500. A total of 36 events occurred, and seven of them are larger than magnitude $7(M \geq 7.0)$. The most remarkable fact is that seven of the earthquakes with a magnitude higher than $7(M \geq 7.0)$ occurred during the last century.

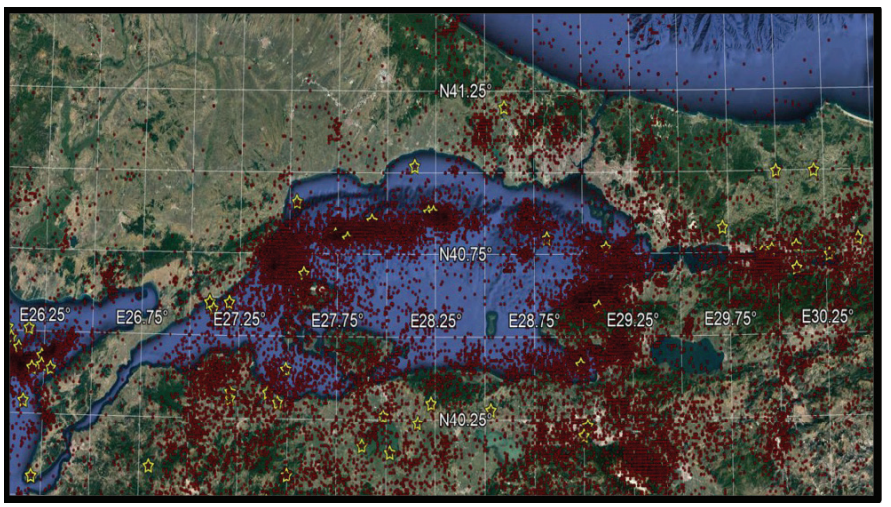

Figure 3. Marmara Region earthquakes during 1900-2021 time period observed by Kandilli Observatory and Earthquake Research Institute (KOERI). Red Circles $1.0 \leq M \leq 4.0$ earthquakes and yellow stars $5 \leq M \leq 7.5$ earthquakes based on KOERI data. Symbol sizes are comparable to the earthquake magnitude

\subsection{Definition of Seismic Sources Modeling}

The seismic source model is evaluated depending on the spatial distribution of earthquakes, regional tectonic structure, and deformational patterns. These earthquakes were collected and processed from the KOERI [11] catalog, which is composed of reported instrumental events $(\mathrm{Mb} \geq 3)$ covering the period from May 12, 1901, to July 31, 2015 (a total of 4,044 events). The following attributes for each event were collected: date, origin time, latitude and longitude, depth, and available reported magnitudes (i.e., mainly $\mathrm{Mb}$ ). The catalog was investigated for duplication, completeness, and time independency of event distribution to achieve the objectives of this study. A basic assumption of our seismic hazard methodology is that earthquake sources are time independent (i.e., random distribution in time). Thus, catalogs must be free of dependent events such as foreshocks and aftershocks; this process often called declustering. We applied the procedure of Gardner and Knopoff [31] to eliminate foreshocks and aftershocks from the catalog.

Figure 4 shows the proposed seismic source model for the region. It is composed of 12 fault sources and three different rupture combinations (Table 1). For these fault sources, we used the characteristic earthquake model with slip rate based on regression analysis to calculate the magnitude-length relationship [32]. To consider fault slip rate, we followed the equation developed by Anderson et al. [33]. We also consider regional GPS studies to determine or to control fault slip rates.

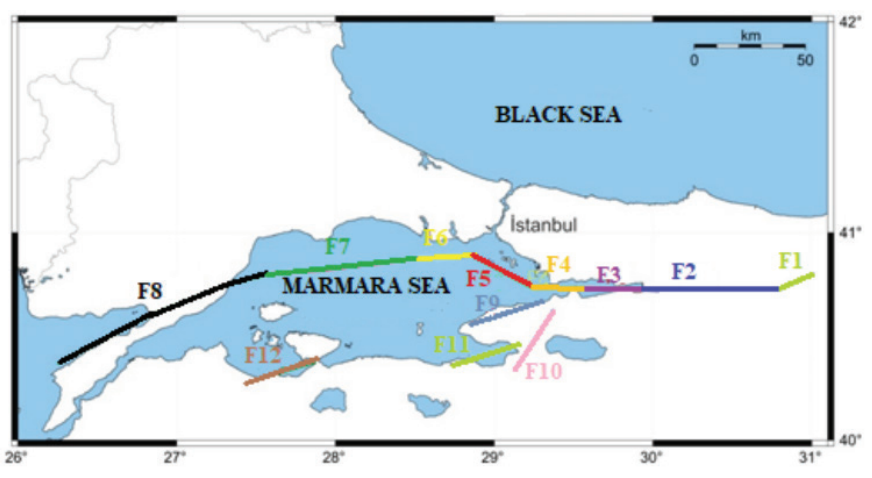

Figure 4. Proposed seismic source model for Marmara Region

In addition to these line sources, we used four major regional area seismic zones to reflect the background seismicity within the investigated region (Figure 5). For these area sources, we calculated some statistical parameters, such as the completeness magnitude $\left(M_{c}\right)$ based on the maximum curvature method [34]. and seismicity of a region (the values of $a$ and $b$ are determined from the frequency magnitude distribution).

For a forecasting experiment similar to this study, the completeness of a catalog is one of the important factors 
Table 1. Fault segmentation information used in this study and shown in Figure 4. Name of the fault, style of faulting, and min/max magnitude

\begin{tabular}{|c|c|c|c|c|c|c|}
\hline Fault segment & Name of the segment & Mechanism & Slip rate & Beta & $\mathbf{M}_{\min }$ & $\mathbf{M}_{\text {max }}$ \\
\hline F2 & Sapanca & $\mathrm{SS} / \mathrm{NC}$ & 25 & 1.84 & 7.1 & 7.3 \\
\hline F2-F3 & & & 25 & 1.84 & 7.3 & 7.5 \\
\hline F4 & Hersek & SS & 25 & 1.84 & 7.1 & 7.3 \\
\hline F5 & Adalar & SS & 27 & 1.84 & 7.2 & 7.3 \\
\hline F6 & Küçükçekmece & SS & 25 & 1.84 & 7.1 & 7.3 \\
\hline F7 & Orta Marmara & SS & 25 & 1.84 & 7.1 & 7.3 \\
\hline F5-F6-F7 & & & 25 & 1.84 & 7.5 & 7.7 \\
\hline F11 & Gemlik & SS & 25 & 2.0723 & 7.1 & 7.3 \\
\hline F12 & Erdek & SS & 25 & 1.9342 & 7.1 & 7.3 \\
\hline
\end{tabular}

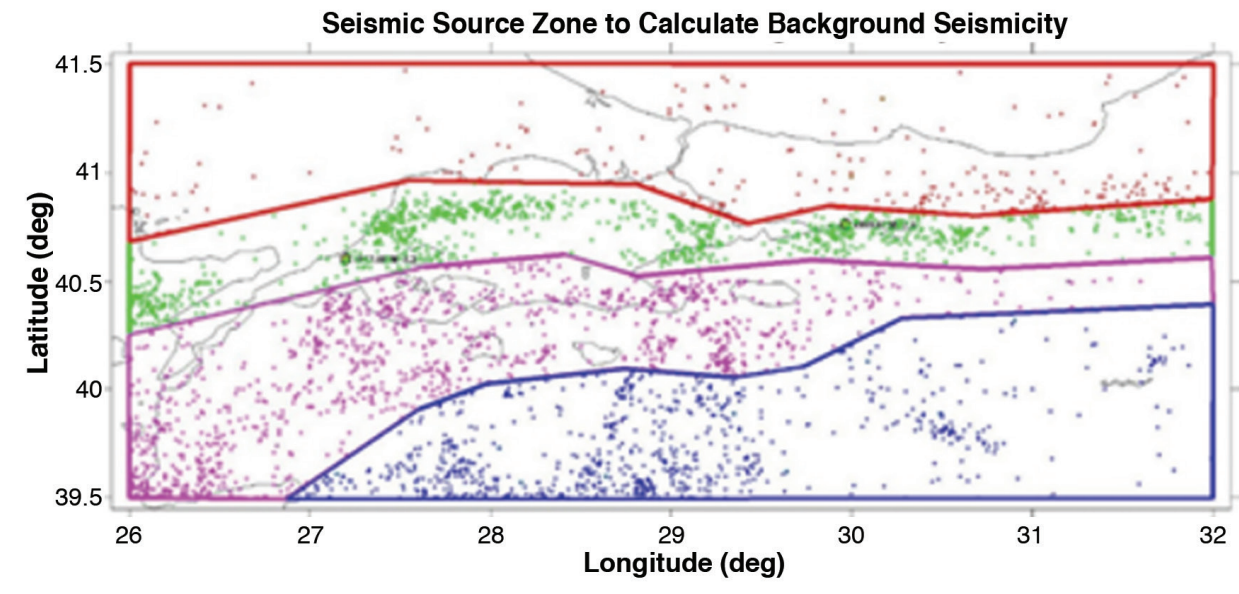

Figure 5. Major regional area seismic zones to reflect background seismicity

because various models require a full catalog to evaluate their parameters accurately. The minimum magnitude of the full catalog, $\left(M_{c}\right)$, is another crucial parameter for seismicity studies. The number of seismographs increases daily all over the world and the analysis procedure improves; thus, $\left(M_{c}\right)$ changes-usually in a decreasing manner-with time in most catalogs.

\subsection{Magnitude Recurrence Relationship}

A catalog with complete earthquake data is essential for the accurate calculation of PSHA. In this study, the magnitude of completeness $\left(\mathrm{M}_{\mathrm{c}}\right)$ was determined based on the maximum curvature method [34]. The a-value and the $b$-value are assigned by using the distribution of frequency magnitude for four regional area seismic zones. These results are summarized in Table 2. The a-value is the value where the line intercepts the y-axis, and the b-value is the inclination of the linear regression. In the literature, the a-value is the productivity. $\left(\mathrm{M}_{\mathrm{c}}\right)$ is the minimum value where the earthquake distribution shows a linear character.

The recurrence relation of earthquakes follows the cumulative Gutenberg-Richter relationship (formula 6 is below):

$\log N(M)=a-b M$ 
Table 2. Statistical parameters ( $a$ - and $b$-value, $M_{\min }-M_{\max }$ ) calculated for area seismic zones

\begin{tabular}{|c|c|c|c|c|c|}
\hline Area seismic zone & Mechanism & a-value & $\mathbf{b}$-value & $\mathbf{M}_{\min }$ & $\mathbf{M}_{\max }$ \\
\hline Zone 1 & Strike slip & 4.19 & 1.07 & 5.0 & 6.5 \\
\hline Zone 2 & Strike slip & 4.27 & 1.09 & 5.0 & 6.5 \\
\hline Zone 3 & Strike slip & 4.28 & 1.15 & 5.0 & 6.5 \\
\hline Zone 4 & Strike slip & 3.01 & 0.89 & 5.0 & 6.5 \\
\hline \multicolumn{7}{|c|}{ mininimum, max: Maximum } \\
\hline
\end{tabular}

The parameters for this relationship were established using geologic data on the historical occurrence of earthquakes and on regional tectonic movements. The $b$-value represents the relative proportion of the earthquakes that have different magnitudes. If the b-value is 1 , then it represents a recurrence relationship that a magnitude 5 earthquake happens once a year and a magnitude 6 earthquake will occur in 10 years. The a-value is the intercept of the recurrence line at $\mathrm{M}$ equals zero. Higher a-values represent a higher overall level of seismicity. The a-value generally changes from one seismic source to another source, but the b-value is stable parameter for a seismic region. A cut-off magnitude of 5 was used as the lowest magnitude value for the definition of magnitude-frequency relationships of the proposed seismic model.

\subsection{Selection of Attenuation Relationships}

Another basic input to seismic hazard computations is an equation (or equations) that is referred to as an attenuation relationship, which predicts the expected ground motion at a site within a given distance from an earthquake of a known magnitude, usually deliberated as the moment magnitude. When the earthquake distributions have been determined for all the seismic sources, then, for a given magnitude, distance, and rupture mechanism, attenuation relationships are applied to evaluate the distribution of ground motion.

Strong ground motion is typically characterized by PGA or $\mathrm{SA}$, or both. Attenuation equations tend to be regionally specific and may depend on site conditions. Assuming that a magnitude $\mathrm{M}$ earthquake occurs at a distance $\mathrm{R}$ (from site to event source), the PofE of ground motion level $\mathrm{z}$ could be calculated. In many parts of the world, numerous studies were accomplished using strong motion records. As a result, a log-normal distribution is generally consistent with the data, having the following mean value (formula 7 is below):

$\operatorname{In}(z)=c_{1}+c_{2} M_{\mathrm{i}}+c_{3} \operatorname{In} R_{\mathrm{i}}+c_{4} R_{\mathrm{j}}$

In this equation, $\mathrm{Z}$ is the ground motion variable, and $\mathrm{c}_{1}$ through $\mathrm{c}_{4}$ are empirically specified constants. $\mathrm{R}_{\mathrm{i}, \mathrm{j}}$ and $\mathrm{M}_{\mathrm{i}}$ are the distance and magnitude, respectively.

The earthquake ground motion attenuation relationships implemented in this study are those developed by the Next-Generation Attenuation (NGA) relationships of Abrahamson and Silva [35], Boore and Atkinson [36], Campbell and Bozorgnia [37], and Chiou and Youngs [38]. These relationships were derived empirically in accordance with the statistical analysis of ground motions recorded during past earthquakes from around the world. These relationships were developed under the Pacific Earthquake Engineering Research Center NGA project and represent the state-of-the-art in attenuation relationships using a large database of strong motion recordings of shallow crustal earthquakes. The validity of the attenuation relationships obtained by using hazard calculations was analyzed in many scientific project and papers in Turkey. Thus, no limitations in the use of these relationships for further studies exist. Some works include Seismic Hazard Harmonization in Europe (ESHM13, Woessner et al. [39]); Earthquake Model of the Middle East Region (Danciu et al. [40]; Danciu et al. [41]; Akkar et al. [42]; Global Earthquake Model; National Earthquake Research Program (UDAP-C-13-06); Ambraseys [43]; Sesetyan et al. [44]; and Demircioğlu et al. [45].

\subsection{Logic Tree Approach Used for Hazard Model}

Two types of uncertainty can be defined in earthquake hazard assessment studies; aleatory uncertainty and epistemic uncertainty [27]. Aleatory uncertainty is a result of the unpredictable nature of the physical process, while epistemic uncertainty is the output of the uncertainties and unknowns in our knowledge. In this research, aleatory uncertainty is presented by the standard deviation of the ground motion attenuation relationships, which is distributed log-normally; this corresponds to the increase in the median hazard. Epistemic uncertainty is presented by the integration of applicable ground motion attenuation relationships and seismic sources. It is achieved by using a logic tree approach (Figure 6). 


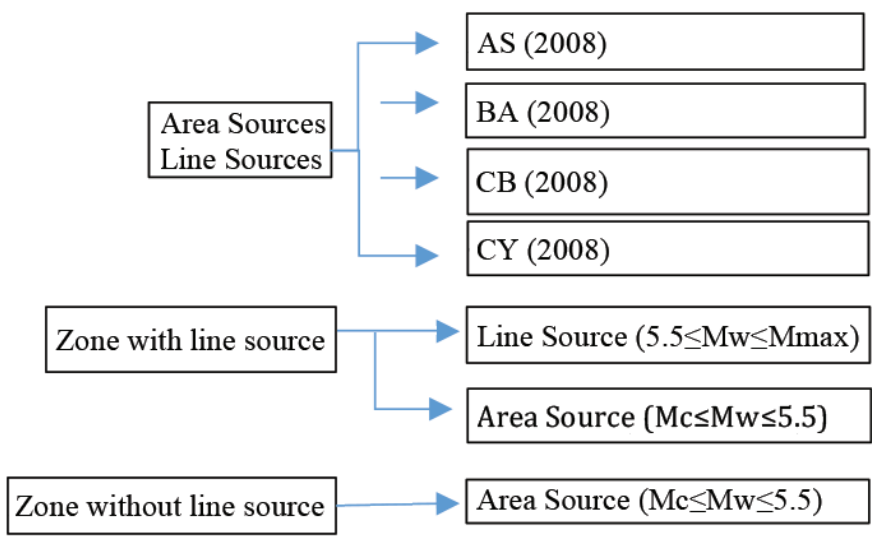

Figure 6. Logic tree approach used for hazard model

\section{Findings and Discussion}

The PSHA is computed by Ez-Frisk Manual software [46] (Risk Engineering, 2015) for a point with the coordinates $40.4160^{\circ} \mathrm{N}$ latitude and $49.9034^{\circ} \mathrm{E}$ longitude. This assessment includes the estimation of the severity of ground shaking on site soil conditions, B/C soil boundary condition $\mathrm{Vs}_{30}=760 \mathrm{~m} / \mathrm{s}$ at a PofE of $2 \%, 10 \%, 29 \%$, and $50 \%$ in 50 years [corresponding return periods $\left(\mathrm{T}_{\mathrm{R}}\right)$, $T_{R}=2,475$ years, $T_{R}=475$ years, $T_{R}=144$ years, and $T_{R}=72$ years]. NGA relationship NGA-W1 is utilized to compute the resultant geometric mean (geo-mean) of 5\% damped horizontal uniform hazard spectra (UHS) for a period range of $0.01 \mathrm{~s}-8 \mathrm{~s}$.

On the basis of the adopted attenuation relationships, for PofEs of $2 \%, 10 \%, 30 \%$, and $50 \%$ in 50 years, this study suggests PGA values in horizontal components not less than $0.694,0.437,0.274$, and $0.200 \mathrm{~g}$, respectively. A summary of PGA, Sa at $0.2 \mathrm{~s}$, and Sa at $1.0 \mathrm{~s}$ values of the different estimated return periods are given for geometric mean and maximum rotated in Table 3. The maximum direction spectral ordinates are obtained by modifying $\mathrm{Sa}^{\mathrm{GM}}$ with period-dependent factors proposed in Huang et al. [47]. These factors are also suggested in the 2009 edition of the National Earthquake Hazard Reduction Program [48], provisions (BSSC, 2009), and the ASCE/SEI 7-10 (ASCE, 2010) document. The resultant 5\% damped horizontal UHS of $T_{R}=2,475$ years, $T_{R}=475$ years, $T_{R}=144$ years, and $T_{R}=72$ years are illustrated in Figure 7 (geomean) and Figure 8 (maxrRotated) for $\mathrm{B} / \mathrm{C}$ soil boundary condition with shear velocity $\mathrm{V}_{\mathrm{S} 30}=760 \mathrm{~m} / \mathrm{s}$.

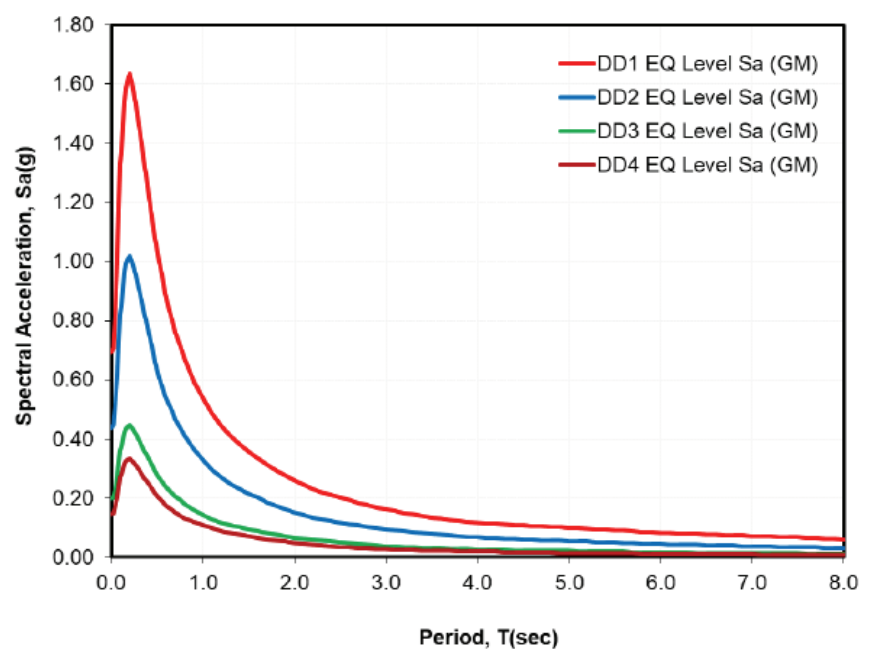

Figure 7. Site-specific UHS for $V_{S 30}=760 \mathrm{~m} / \mathrm{s}$

UHS: Uniform hazard spectra, EQ: Earthquake, GM: Geometric mean

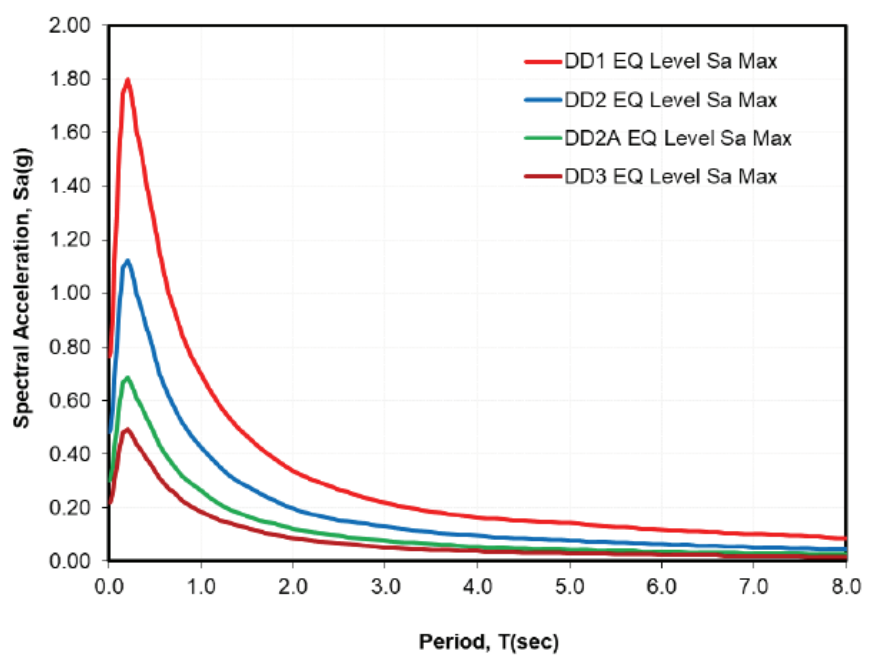

Figure 8. Site-specific UHS for $V_{S 30}=760 \mathrm{~m} / \mathrm{s}$ (max rotated). UHS: Uniform hazard spectra, EQ: Earthquake, Max: Maximum

Table 3. Summary of PGA in vertical components, Sa (0.2) and Sa (1.0) values of different estimated return periods assuming soil shear velocity $V_{S 30}=760 \mathrm{~m} / \mathrm{s}$

\begin{tabular}{|c|c|c|c|c|c|c|c|c|}
\hline \multirow{2}{*}{ EQ level } & \multirow{2}{*}{$\begin{array}{l}\text { Return periods } \\
\text { (years) }\end{array}$} & \multirow{2}{*}{$\begin{array}{c}\text { Exc. Prob. in } 50 \\
\text { years }(\%)\end{array}$} & \multicolumn{2}{|c|}{ Max. PGA (g) } & \multicolumn{2}{|c|}{$\mathrm{Sa}(\mathrm{T}=0.2 \mathrm{sec})$} & \multicolumn{2}{|c|}{ Sa $(\mathrm{T}=1.0 \mathrm{sec})$} \\
\hline & & & Geo-mean & Max-rot & Geo-mean & Max-rot & Geo-mean & Max-rot \\
\hline E-1 & 2475 & 2 & 0.694 & 0.763 & 1.634 & 1.797 & 0.537 & 0.698 \\
\hline E-2 & 475 & 10 & 0.437 & 0.481 & 1.019 & 1.121 & 0.328 & 0.426 \\
\hline E-2A & 144 & 30 & 0.274 & 0.301 & 0.623 & 0.685 & 0.204 & 0.265 \\
\hline E-3 & 72 & 50 & 0.200 & 0.219 & 0.448 & 0.492 & 0.142 & 0.184 \\
\hline \multicolumn{9}{|c|}{ PGA: Peak ground acceleration, EQ: Earthquake } \\
\hline
\end{tabular}


The vertical spectrum was obtained from the product of the average of $\mathrm{V} / \mathrm{H}$ ratio GMPEs and for PofEs of $2 \%, 10 \%, 30 \%$, and $50 \%$ in 50 years. The $\mathrm{V} / \mathrm{H}$ ratios suggested by Gülerce and Abrahamson [49] are utilized, and the site-specific vertical spectrum is obtained from the product of average of V/H ratio GMPEs. Site-specific vertical spectra for B/C boundary site conditions with shear velocity $\mathrm{V}_{\mathrm{S} 30}=760 \mathrm{~m} / \mathrm{s}$ are illustrated in Figure 9 and Table 4.

Table 4. Summary of PGA in vertical components, Sa (0.2), and Sa (1.0) values of different estimated return periods assuming soil shear velocity $V_{S 30}=760 \mathrm{~m} / \mathrm{s}$

\begin{tabular}{|c|c|c|c|c|c|}
\hline $\begin{array}{c}\text { EQ } \\
\text { level }\end{array}$ & $\begin{array}{c}\text { Return } \\
\text { periods } \\
\text { (years) }\end{array}$ & $\begin{array}{c}\text { Exc. Prob. } \\
\text { in 50 years } \\
\text { (\%) }\end{array}$ & $\begin{array}{c}\text { Max. PGA } \\
\text { (g) }\end{array}$ & $\begin{array}{c}\text { Sa } \\
(\mathbf{T}=\mathbf{0 . 2} \\
\mathbf{s e c})\end{array}$ & $\begin{array}{c}\text { Sa } \\
(\mathbf{T = 1 . 0} \\
\mathbf{s e c})\end{array}$ \\
\hline E-1 & $\mathbf{2 4 7 5}$ & $\mathbf{2}$ & 0.504 & 0.908 & 0.319 \\
\hline E-2 & $\mathbf{4 7 5}$ & $\mathbf{1 0}$ & 0.318 & 0.566 & 0.195 \\
\hline E-2A & $\mathbf{1 4 4}$ & $\mathbf{3 0}$ & 0.145 & 0.249 & 0.084 \\
\hline E-3 & $\mathbf{7 2}$ & $\mathbf{5 0}$ & 0.107 & 0.186 & 0.604 \\
\hline \multicolumn{6}{|c|}{ PGA: Peak ground acceleration, EQ: Earthquake } \\
\hline
\end{tabular}

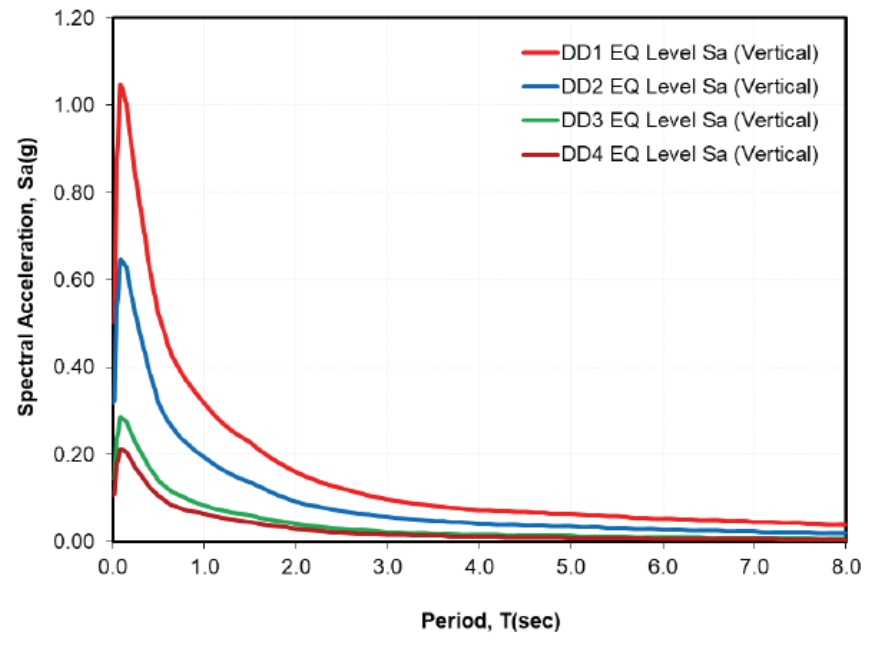

Figure 9. Site-specific UHS for $V_{S 30}=760 \mathrm{~m} / \mathrm{s}$ (vertical component) UHS: Uniform hazard spectra, EQ: Earthquake
Finally, to provide a better perspective to evaluate the results of this study, Table 5 shows a summary of PGA, Sa at $0.2 \mathrm{~s}$, and $\mathrm{Sa}$ at $1.0 \mathrm{~s}$ values compared with the RHA seismic code [7] and the Turkey Building Earthquake Code [50].

\section{Conclusion}

This study aims to develop probabilistic seismic hazard assessments for the coastal area of Haydarpaşa Port site to clarify the seismic loading evaluation of marine ports around İstanbul. The calculation was performed for B/C boundary conditions and the findings are for the average of the two horizontal components of ground motion. The estimation of seismic hazard depends not only on the regional tectonics and the precise characterization of the faults within the area of interest, but also on the implemented analysis procedures and the variety of physical and empirical models, which are considered as the most suitable models for the required analysis.

In conclusion, with the aim of implementing the optimum empirical or physical models and calibrating the uncertainty in the findings accurately, this study used a set of alternative identification of the sources of seismic ground motion in addition to a multi-model simulation of seismic ground motion attenuation. This work presents a fair discussion of the foremost applicable assessments of literature in this field of interest. All works agree that the engineers who are involved in the long run in the design process are a key component. Engineers are expected to analyze the literature to make a precise decision as to whether the selected safety criteria are applicable to the relevant behavior objectives or not. This study aims to support practicing engineers in mastering seismic design codes. This training is considered an urgent need in implementing the standards and codes accurately for marine ports.

Funding: This work was supported by the TÜBITTAK Career Development Program (3501), project no: 116Y091.

Table 5. Summary of PGA in vertical components, Sa (0.2), and Sa (1.0) values of different estimated return periods assuming soil shear velocity $V_{S 30}=760 \mathrm{~m} / \mathrm{s}$

\begin{tabular}{|c|c|c|c|c|c|c|c|c|c|c|c|}
\hline \multirow[b]{2}{*}{ EQ level } & \multirow[b]{2}{*}{$\begin{array}{c}\text { Return periods } \\
\text { (years) }\end{array}$} & \multirow[b]{2}{*}{$\begin{array}{l}\text { Exc. Prob. in } \\
50 \text { years (\%) }\end{array}$} & \multicolumn{3}{|c|}{ Max. PGA (g) } & \multicolumn{3}{|c|}{$\mathrm{Sa}(\mathrm{T}=0.2 \mathrm{sec})$} & \multicolumn{3}{|c|}{ Sa $(T=1.0 \mathrm{sec})$} \\
\hline & & & $\begin{array}{l}\text { This } \\
\text { study }\end{array}$ & $\begin{array}{l}\text { RHA- } \\
2007\end{array}$ & TBEC-2018 & $\begin{array}{l}\text { This } \\
\text { study }\end{array}$ & $\begin{array}{l}\text { RHA- } \\
2007\end{array}$ & $\begin{array}{l}\text { TBEC- } \\
2018\end{array}$ & $\begin{array}{l}\text { This } \\
\text { Study }\end{array}$ & $\begin{array}{l}\text { RHA- } \\
2007\end{array}$ & $\begin{array}{l}\text { TBEC- } \\
2018\end{array}$ \\
\hline E-2 & 475 & 10 & 0.437 & 0.48 & 0.387 & 1.019 & 1.19 & 0.945 & 0.328 & 0.58 & 0.261 \\
\hline E-3 & 72 & 50 & 0.200 & 0.25 & 0.163 & 0.448 & 0.62 & 0.376 & 0.142 & 0.23 & 0.163 \\
\hline
\end{tabular}

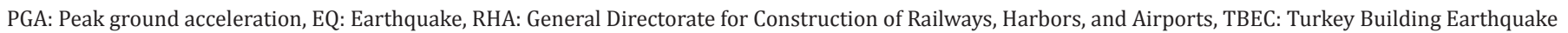
Code 


\section{References}

[1] H. Tsuchida, "History of earthquake-induced damage on port facilities in Japan." J Foundation Engineering \& Equipment, vol. 315, 2-4 in Japanese, 2003.

[2] Port and Harbour Research Institute, Handbook on liquefaction remediation of reclaimed land, Ports and Harbours Bureau, Tokyo: Coastal Development Institute of Technology, 1997.

[3] R. Boulanger, et al. "Performance of waterfront structures," Kocaeli, Turkey, Earthquake Reconnaissance Rep. in Chap. 13, Supplement A to Earthquake Spectra, T. L. Youd, J.-P. Bardet, and J. D. Bray Eds., İstanbul: Yıldız Teknik Üniversitesi, 2000, pp. 295-310.

[4] A.R. Gunbak, O. Muyesser, and Y. Yuksel, "Damages recorded at the coastal and port structures around Izmit Bay under the August 17, 1999 Earthquake." Presented at PIANC Buenos Aires Conf., 2000. Buenos Aires, Argentina, 2000.

[5] Y. Yüksel, B. Alpar, A. Yalciner, E. Cevik, O. Ozguven and Y. Celikoglu, "Effects of the Eastern Marmara Earthquake on the marine structures and coastal areas." Proceedings of the Institution of Civil Engineers Water and Maritime Engineering, vol. 156, pp. 147-163, Jun 2003.

[6] B.M. Sumer, A. Kaya, and N.E.O. Hansen, "Impact of liquefaction on coastal structures in the 1999 Kocaeli, Turkey Earthquake." in 12th Int. Offshore and Polar Engineering Conf., KitaKyushu: Japan, vol. 2, 2002, pp. 504-511.

[7] Kıyı ve Liman Yapıları, Demiryolları ve Hava Meydanları İnşaatlarına İlişkin Deprem Teknik Yönetmeliği, Ulaştırma Bakanlığı, Ankara, Ağustos 2007.

[8] M. Cubrinovski, et al. "Liquefaction-induced damage and CPT characterization of the reclamation at centreport Wellington." Bulletin of the Seismological Society of America, vol 108, March 2018.

[9] Ulasim ve Dagitim Tesisleri İçin Deprem Yönetmelikleri Hazirlanmasi ve Musavirlik Hizmetleri Danismanlik Hizmet Alimi İsi, Yüksel Proje, Nihai Rapora Esas Taslak Rapor (ARA RAPOR-3), Kıyı ve Liman Yapıları (Sektör: Ulaşım Tesisleri - A3) Mayis 2019.

[10] The Turkish Statistical Institute, [Online] Available from: https://www.tuik.gov.tr

[11] Boğaziçi University, Kandilli Observatory and Earthquake Research Institute (KOERI), Regional Earthquake and Tsunami Monitoring Center, [Online] Available from:www.koeri.boun. edu.tr.

[12] R. Armijo, B. Meyer, A. Hubert and A. Barka, "Westward propagation of the North Anatolian fault into the northern Aegean: timing and kinematics," Geology, vol. 27, pp. 267-270, April 2016.

[13] A.C. Yalciner, et al. "Evaluation of tsunami scenario for western Peloponnese, Greece". Bollettino di Geofisica Teorica ed Applicata. vol. 55, pp. 485-500. DOI 10.4430/bgta0126.

[14] T. Hori, A. Pinar, O. Necmioglu, M. Hori and A. Nishizawa, "Special issue the next Marmara earthquake: disaster mitigation, recovery, and early warning, Earth, Planets and Space, vol. 69, May 2017.

[15] C.A. Cornell, "Engineering seismic risk analysis", Bulletin of the Seismological Society of America, vol. 58, pp. 1583-1606, Oct 1968.
[16] R.K. McGuire, "FORTRAN program for seismic risk analysis," Virginia, USA, U.S. Geological Survey Open-File Rep. 76-67, 1976.

[17] R. Gutenberg, and C.F. Richter, "Frequency of earthquakes in California." Bulletin of the Seismological Society of America, vol. 34, pp. 185-188, Oct 1944.

[18] A.A. Barka and K. Kadinsky-Cade, "Strike-slip fault geometry in Turkey and its influence on earthquake activity," Tectonics, vol. 7, pp. 663-684, Jun 1988.

[19] J.F. Dewey and A.M.C. Şengör, "Aegean and surrounding regions: Complex multi plate and continuum tectonics in convergent zone:" Geological Society America Bullletin, vol. 90, pp. 84-92, Jan 1979.

[20] A.M.C. Şengör, N. Görür and F. Şaroğlu, "Strike-slip faulting and related basin formation in zones of tectonic escape: Turkey as a case study," in strike-slip Faulting and Basin Formation, K.T. Biddle, and N. Christie-Blick, Eds. İstanbul: The Society of Economic Paleontologists and Mineralogists Publications, vol. 37, 1985, pp. 227-265.

[21] G. Orgulu, "Seismicity and source parameters for small-scale earthquakes along the splays of the North Anatolian Fault (NAF) in the Marmara Sea," Geophysical Journal International, vol. 184, pp. 385-404, Jan 2011.

[22] N. Pınar, Marmara Denizi Havzasının Sismik Jeoloji ve Meteorolojisi/Géologie et Météorologie Sismique du Bassin de Mer Marmara, İstanbul: Kenan Matbaası, 1943.

[23] M.N. Toksöz, A.F. Shakal and A.J. Micheal, "Space-time migration of earthquakes along the North Anatolian Fault Zone and seismic gaps," Pure and Applied Geophysics, vol. 117, pp. 1258-1270, Nov 1979.

[24] N. Pondard, R. Armijo, G.C.P. King, B. Meyer and F. Flerit, "Fault interactions in the Sea of Marmara pullapart (North Anatolian Fault): earthquake clustering and propagating earthquake sequences," Geophysical Journal International, vol. 171, pp. 1185-1197, Aug 2007.

[25] A.M.C. Şengör, et al. "The geometry of the North Anatolian transform fault in the Sea of Marmara and its temporal evolution: implications for the development of intracontinental transform faults." Canadian Journal of Earth Sciences, vol. 51, pp. 222-242, Feb 2014.

[26] N.N. Ambraseys, "The seismic activity of the Marmara Sea Region over the last 2000 years," Bulletin of the Seismological Society of Amerika, vol. 92, pp. 1-18, Feb 2002.

[27] M. Erdik, M. Demircioglu, K. Sesetyan, E. Durukal and B. Siyahi, "Assessment of probabilistic earthquake hazard in The Marmara region, Soil Dynamics and Earthquake Engineering, vol. 24, pp. 605-631.

[28] H. Hébert, F. Schindelé, Y. Altinok, B. Alpar and C. Gazioglu, "Tsunami hazard in the Marmara Sea (Turkey): a numerical approach to discuss active faulting and impact on the Istanbul coastal areas," Marine Geology, vol. 215, pp. 23-43, Feb 2005.

[29] N.N. Ambraseys, and C.F. Finkel, "Long-term seismicity of İstanbul and of the Marmara Sea region," Terra Nova, vol. 3, pp. 527-539, Sep 1991.

[30] E. Kalkan, P. Gülkan, N. Yilmaz and M. Çelebi, "Reassessment of probabilistic seismic hazard in the Marmara region," Bulletin of the Seismological Society of America, vol. 99, pp. 2127-2146, Aug 2009. 
[31] J.K. Gardner and L. Knopoff, "Is the sequence of earthquakes in southern california, with aftershocks removed, poissonian?" Bulletin of the Seismological Society of America, vol. 64-5, pp. 1363-1367, Oct 1974.

[32] T.C. Hanks and W.H. Bakun, "M-log A observations of recent large earthquakes," Bulletin of the Seismological Society of America, vol. 98, 490-494, Feb 2008.

[33] J.G. Anderson, S.G. Wesnousky, and M. Stirling, "Earthquake size as a function of fault slip rate," Bulletin of the Seismological Society of America vol. 86, pp. 683-690, Jun 1996.

[34] S. Wiemer, and M. Wys, "Minimum magnitude of completeness in earthquake catalogs: examples from Alaska, the western United States and Japan," Bulletin of the Seismological Society of America, vol. 90, pp. 859-869, Aug 2000.

[35] N.A. Abrahamson and W.J. Silva, "Summary of the abrahamson \& silva NGA ground motion relations," Earthquake Spectra, vol. 24, pp. 67-97, Dec 2019.

[36] D.M. Boore and G.M. Atkinson, "Ground-motion prediction equations for the average horizontal component of pga, pgv, and 5\%-damped PSA at spectral periods between $0.01 \mathrm{~s}$ and $10.0 \mathrm{~s}$," Earthquake Spectra, vol. 24, pp: 99-138, Dec 2019.

[37] K.W. Campbell and Y. Bozorgnia, "NGA ground motion model for the geometric mean horizontal component of pga, pgv, pgd and $5 \%$ damped linear elastic response spectra for periods ranging from 0.01 to 10 s", Earthquake Spectra, vol. 24, pp. 139-171, Dec 2019.

[38] B. Chiou, R.R and Youngs, "An NGA model for the average horizontal component of peak ground motion and response spectra," Earthquake Spectra, vol. 24, pp. 173-215. Dec 2019.

[39] J. Woessner, L. Danciu D. Giardini and the SHARE consortium, "The 2013 European Seismic Hazard Model: key components and results," Bulletin of Earthquake Engineering, pp. 3553-3596, Jul 2015.

[40] L. Danciu, O. Kale and S. Akkar, "The 2014 Earthquake model of the Middle East: Ground motion model and uncertainties," Bulletin Earthquake Engineering, pp. 3497-3533, Aug 2016.
[41] L. Danciu, K. Şeşetyan, M. Demircioglu, M. Erdik, D. Giardini, "The 2014 Earthquake Model of the Middle East: seismogenic sources." Bull Earthquake Eng 16, 3465-3496 (2018). https:// doi.org/10.1007/s10518-017-0096-8.

[42] S. Akkar, et al. "Reference database for seismic ground-motion in Europe (RESORCE)," Bulletin of Earthquake Engineering, vol. 12, pp. 311-339, Sept 2013.

[43] N.N. Ambraseys, "The seismic activity of the Marmara Sea Region over the last 2000 years," Bulletin of the Seismological Society of Amerika, vol. 92, pp. 1-18. Feb 2002.

[44] K. Sesetyan, et al. "A probabilistic seismic hazard assessment for the Turkish territory-part I: the area source model," Bulletin of Earthquake Engineering, vol. 16, 3367-3397, Sept 2018.

[45] M.B. Demircioğlu, et al. "A probabilistic seismic hazard assessment for the Turkish territory: part II-fault source and background seismicity model." Bulletin of Earthquake Engineering, vol.16, pp. 3399-3438, Sept 2018.

[46] Ez-Frisk Manual, "Software for Earth quake Ground Motion Estimation," Risk Engineering INC, [Online]. Available: http:// www.ez-frisk.com/. [Accessed: 2015].

[47] Y.N. Huang, A.S. Whittaker and N. Luco, "Maximum spectral demands in the near-fault region. earthquake Spectra," vol. 24 pp. 319-341. Dec 2008.

[48] Building Seismic Safety Council for the Federal Emergency Management Agency, National Earthquake Hazard Reduction Program NEHRP (2009). 2009 NEHRP Recommended Provisions for New Buildings and Other Structures (FEMA 450), Washington: Building Seismic Safety Council National Institute of Building Sciences, 2004.

[49] Z. Gülerce and N.A. Abrahamson, "Site-specific design spectra for vertical ground motion." Earthquake Spectra, vol. 27 pp. 1023-1047, Nov 2011.

[50] Türkiye Bina Deprem Yönetmeliği, Afet ve Acil Durum Yönetimi Başkanlığı, Ankara, 2018. 